\title{
Cellular Growth of Delta-Pearlite Formed by Carburization of Ternary Iron Alloys
}

\author{
By Takashi Saito*, Taketo Sakuma** and Taiji Nishizawa**
}

\begin{abstract}
Eutectoid composition and microstructure of $\delta$-pearlite were studied in the carburized $\mathrm{Fe}-\mathrm{Cr}-\mathrm{M}$ and $\mathrm{Fe}-\mathrm{W}-\mathrm{M}$ ternary alloys, where $\mathrm{M}$ is the third element. The chromium or tungsten content in the eutectoid alloy decreases with addition of a ferrite-stabilizing element and increases with addition of an austenite-stabilizing element.

The alloying element causes the change in shape of $\delta$-ferrite $/ \delta$-pearlite interface from planar to cellular. Measurements of solute distribution in front of the cellular interface have revealed that a spike of substitutional solute concentration ahead of the tip of the cell is produced and solute segregation occurs at the cell boundary. The formation of the cellular structure is caused by the generation of the carbon-supersaturated region in $\delta$-ferrite due to the presence of the spike.
\end{abstract}

(Received February 7, 1980)

\section{Introduction}

It has been reported in a previous paper ${ }^{(1)}$ that the morphology and growth kinetics of $\delta$-pearlite produced by carburizing binary iron alloys are similar to those of binary eutectic structure formed by unidirectional solidification. It is to be expected that the

* Graduate School, Tohoku University, Sendai. Present address: Toyota Central Research and Development Laboratories Inc., Nagoya 468, Japan.

** Department of Materials Science, Faculty of Engineering, Tohoku University, Sendai 980, Japan. $\delta$-pearlite structure changes with addition of a third element because a remarkable change in the solid/liquid interface as well as the configuration of each phase in eutectic structure due to additives have been found in eutectic solidification. The morphological changes in solidification structure has been understood from the idea of interfacial instability caused by the partitioning of a third element at the solidification front ${ }^{(2)}$. The idea has also been applied for explaining the shape change of the solid/solid interface during reaction diffusion in ternary alloys ${ }^{(3) \sim(5)}$, precipitation from supersaturated solid solutions ${ }^{(6)}$ and growth of oxide films ${ }^{(7)}$.

The present work was carried out to examine

Table 1 Chemical composition of specimens. (in wt $\%$ )

\begin{tabular}{ccc|ccc|ccc}
\hline Alloys & Cr & M & Alloys & Cr & M & Alloys & W & M \\
\hline Fe-Cr-Si & 17.7 & 0.03 & Fe-Cr-Ni & 17.0 & 0.33 & Fe-W-Si & 15.3 & 0.52 \\
& 17.4 & 0.15 & & 22.9 & 0.40 & & 10.0 & 0.93 \\
& 16.7 & 0.28 & & 19.3 & 0.47 & & 14.4 & 1.03 \\
& 22.3 & 0.66 & & 19.7 & 1.03 & & 12.9 & 2.01 \\
& 18.7 & 0.75 & & 17.1 & 1.03 & & 12.0 & 3.00 \\
& 17.7 & 0.81 & & 24.4 & 1.07 & Fe-W-Ni & 15.7 & 0.32 \\
& 16.9 & 1.80 & & 23.2 & 1.99 & & 9.70 & 0.98 \\
Fe-Cr-Mo & 12.6 & 2.88 & & 19.6 & 2.18 & & 15.4 & 1.08 \\
& 16.1 & 1.10 & & 22.1 & 3.01 & & 16.8 & 2.21 \\
& 14.8 & 2.11 & Fe-Cr-Mn & 23.6 & 1.41 & Fe-W-Mn & 15.3 & 1.04 \\
& 10.3 & 2.96 & & 23.3 & 1.66 & & 14.6 & 1.41 \\
& 12.1 & 3.19 & & 20.2 & 1.80 & & 14.4 & 2.45 \\
& 14.4 & 3.21 & & 21.2 & 2.21 & Fe-W-Cr & 15.4 & 3.71 \\
& 16.0 & 3.44 & Fe-Cr-P & 16.7 & 0.53 & & 12.8 & 3.35 \\
& 19.3 & 3.04 & & & & & 10.1 & 4.98 \\
\hline
\end{tabular}


the effect of alloying elements, $\mathrm{Si}, \mathrm{Mo}, \mathrm{Ni}$, $\mathrm{Mn}, \mathrm{Cr}$ and $\mathrm{P}$ on the morphology of $\delta$-pearlite produced by carburization. The distribution of alloying elements in $\delta$-ferrite was also determined to analyse the mechanism of formation of cellular eutectoid structure.

\section{Experimental Procedure}

The compositions of $\mathrm{Fe}-\mathrm{Cr}-\mathrm{M}$ and $\mathrm{Fe}-\mathrm{W}-\mathrm{M}$ ternary alloys used are listed in Table 1 . The specimen preparation technique and the subsequent carburizing treatment are almost the same as those described previously ${ }^{(1)}$. Cubeshaped specimens with dimensions $8 \mathrm{~mm} \times$ $8 \mathrm{~mm} \times 8 \mathrm{~mm}$ were carburized at temperatures between 1100 and $1500 \mathrm{~K}$ for the period from $30 \mathrm{~min}$ to $25 \mathrm{~h}$. After the carburizing treatment, the specimens were quenched into ice water, and then metallographically examined.

Concentration profile of solutes ahead of $\delta$-pearlite was measured by Shimazu ARLEMX microanalyzer with a take-off angle of $52.5^{\circ}$. The operating condition was the accelerated voltage $20 \mathrm{kV}$, beam diameter $\sim 1 \mu \mathrm{m}$ and specimen current $0.03 \mu \mathrm{A}$. Diffracting crystals used were $\mathrm{LiF}$ and $\mathrm{SiO}_{2}$. Relative X-ray intensities $I_{M}$ were converted to weight fractions $c_{\mathrm{M}}$ by the following equation ${ }^{(8)}$ :

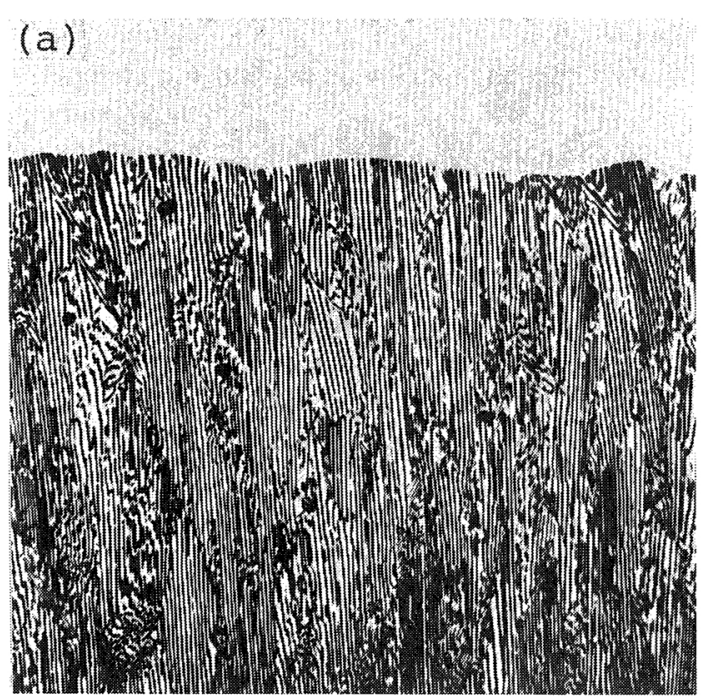

Longitudinal Section

$$
\frac{1-I_{M}}{I_{M}}=\alpha_{M} \frac{1-c_{M}}{c_{M}} .
$$

The conversion parameters $\alpha_{M}$ were obtained by calibration experiments as follows: $\alpha_{\mathrm{Cr}}=$ $0.778, \alpha_{\mathrm{W}}=1.815, \alpha_{\mathrm{Mo}}=1.501, \alpha_{\mathrm{Si}}=1.243$ and $\alpha_{\mathrm{Ni}}=1.100$.

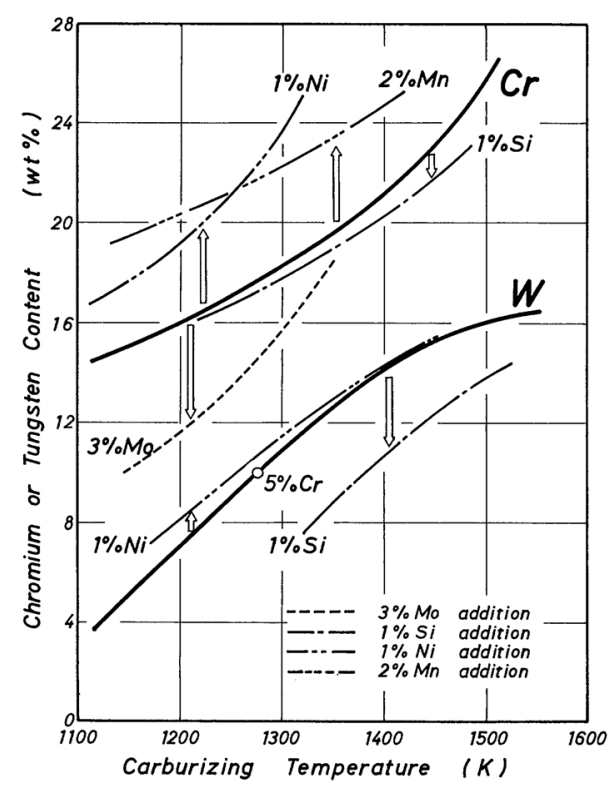

Fig. 1 Change in $\delta$-eutectoid composition due to a small addition of alloying elements in $\mathrm{Fe}-\mathrm{Cr}-\mathrm{C}$ and Fe-W-C alloy.

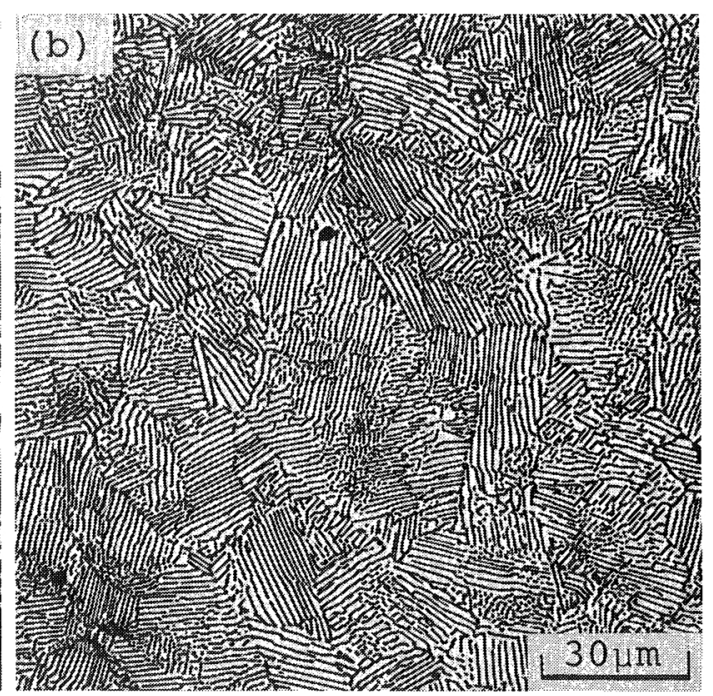

Transverse Section

Photo. 1 Delta-pearlite produced by carburizing $\mathrm{Fe}-17.7 \mathrm{wt} \% \mathrm{Cr}$ alloy at $1273 \mathrm{~K}$. 


\section{Results and Discussion}

\section{Eutectoid composition}

Figure 1 shows the change in chromium or tungsten content for obtaining the eutectoid structure by an addition of alloying element. Thick lines in Fig. 1 shows the eutectoid composition in carburizing $\mathrm{Fe}-\mathrm{Cr}$ or $\mathrm{Fe}-\mathrm{W}$ binary alloys at each temperature. It is known from Fig. 1 that the chromium content or tungsten content in the eutectoid alloys decreases with addition of a ferrite-stabilizing element such as silicon or molybdenum and increases with addition of an austenitestabilizing element such as nickel or manganese.

\section{Microstructure}

(1) Structure in $\mathrm{Fe}-\mathrm{Cr}-\mathrm{M}-\mathrm{C}$ alloys

Photograph 1 shows longitudinal and transverse sections of $\delta$-pearlite produced by (a)
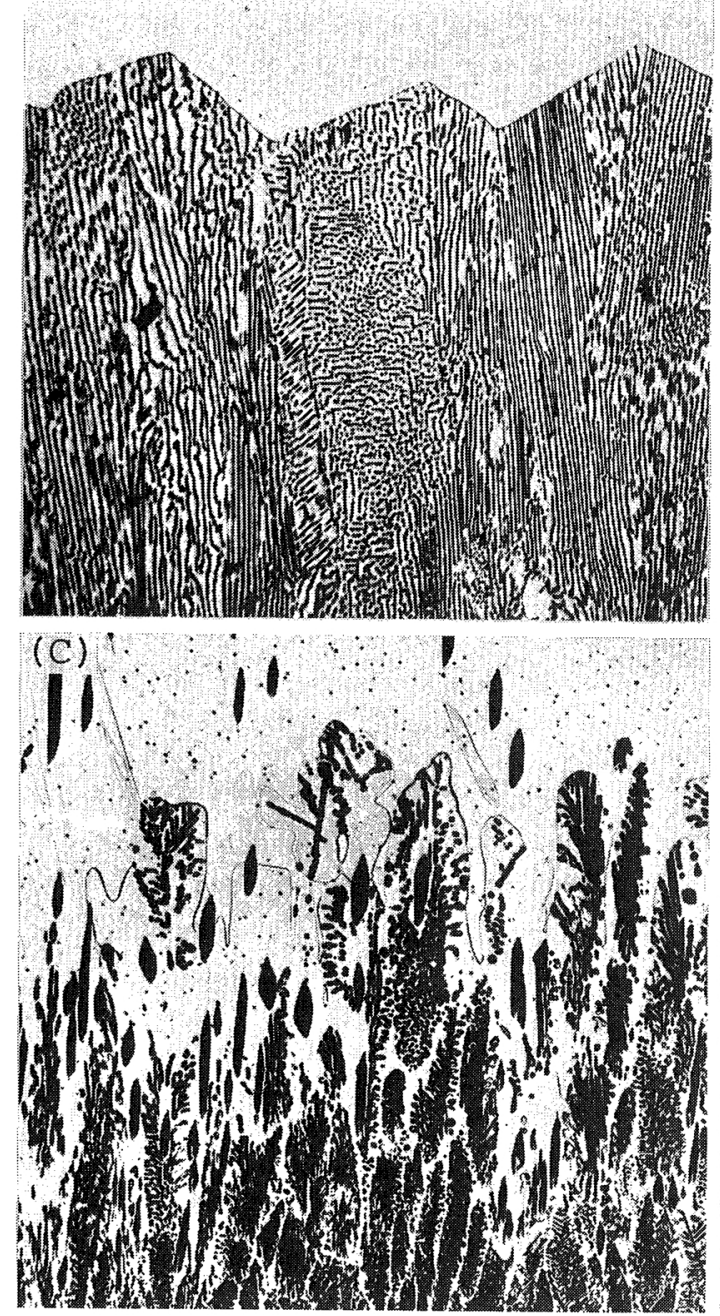

(b)
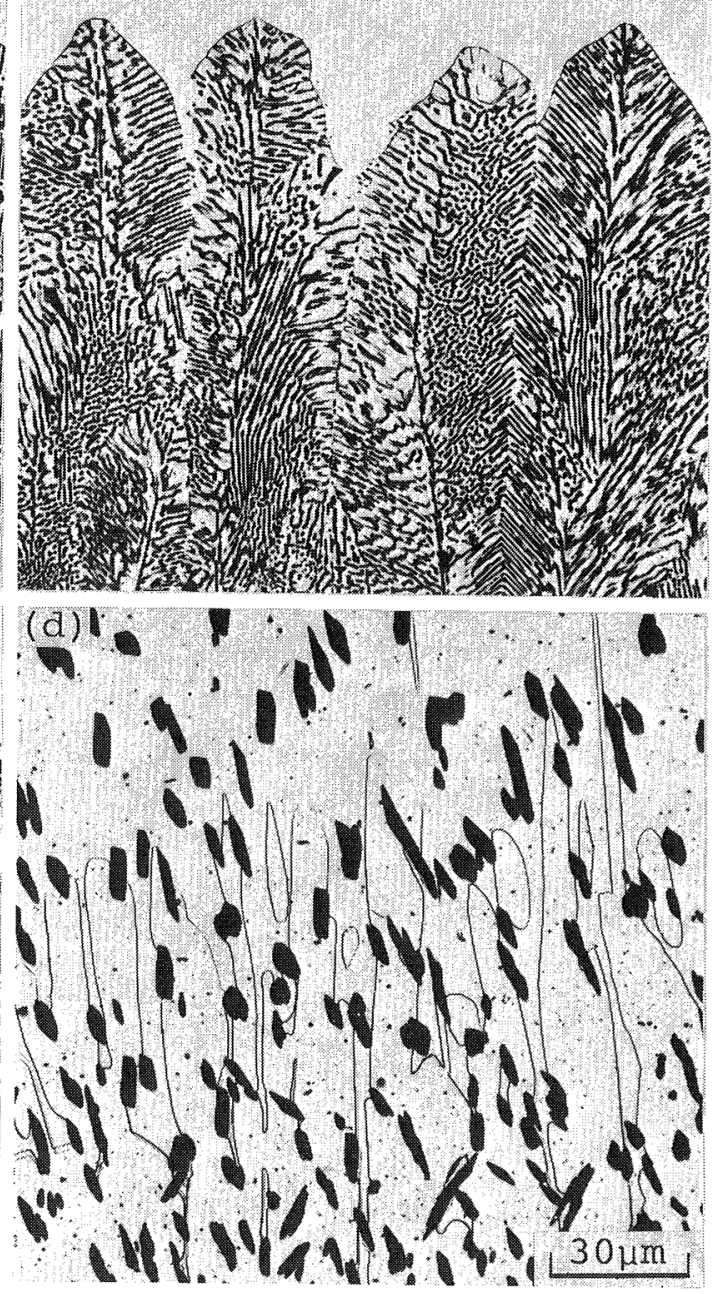

Photo. 2 Microstructures obtained by carburizing $\mathrm{Fe}-\mathrm{Cr}-\mathrm{Si}$ alloys. (a) $\mathrm{Fe}-16.7 \mathrm{wt} \% \mathrm{Cr}-$ $0.28 \mathrm{wt} \% \mathrm{Si}$ alloy carburized at $1273 \mathrm{~K}$. (b) $\mathrm{Fe}-17.7 \mathrm{wt} \% \mathrm{Cr}-0.81 \mathrm{wt} \% \mathrm{Si}$ alloy carburized at $1273 \mathrm{~K}$. (c) $\mathrm{Fe}-16.9 \mathrm{wt} \% \mathrm{Cr}-1.80 \mathrm{wt} \% \mathrm{Si}$ alloy carburized at $1293 \mathrm{~K}$. (d) $\mathrm{Fe}-12.6 \mathrm{wt} \% \mathrm{Cr}-$ $2.88 \mathrm{wt} \% \mathrm{Si}$ alloy carburized at $1253 \mathrm{~K}$. 
carburizing the $\mathrm{Fe}-17.7 \mathrm{wt} \% \mathrm{Cr}$ alloy. It is seen in the photograph that lamellar structure composed of austenite and $\mathrm{M}_{23} \mathrm{C}_{6}$ carbide is aligned parallel to the carburizing direction and that the reaction front is planar.

Photograph 2 shows the effect of silicon on the morphology of $\delta$-pearlite in $\mathrm{Fe}-\mathrm{Cr}-\mathrm{C}$ alloy. The reaction front changes from planar to cellular with an addition of silicon up to about $1 \mathrm{wt} \%$. In the alloys with more than about $2 \mathrm{wt} \% \mathrm{Si}$, the pearlitic structure was not formed i.e., austenite and carbide were seen to grow independently as in Photo. 2(d).
The cellular structure was obtained by carburizing $\mathrm{Fe}-\mathrm{Cr}-\mathrm{Mo}$ alloys with more than $2 \mathrm{wt} \% \mathrm{Mo}$ as shown in Photo. 3. The independent growth of austenite and carbide as seen in Photo. 2(c) or (d) was not observed in the alloys up to $3.44 \mathrm{wt} \% \mathrm{Mo}$. In Photo. 3(a), the morphology of carbides looks dendritic, being composed of primary rod-shaped arms parallel to growth direction and of secondary rodshaped arms nearly perpendicular to the primary arms. However, it is known in Photo. 3(b) that the primary arms are composed of two plates crossing each other at an angle of

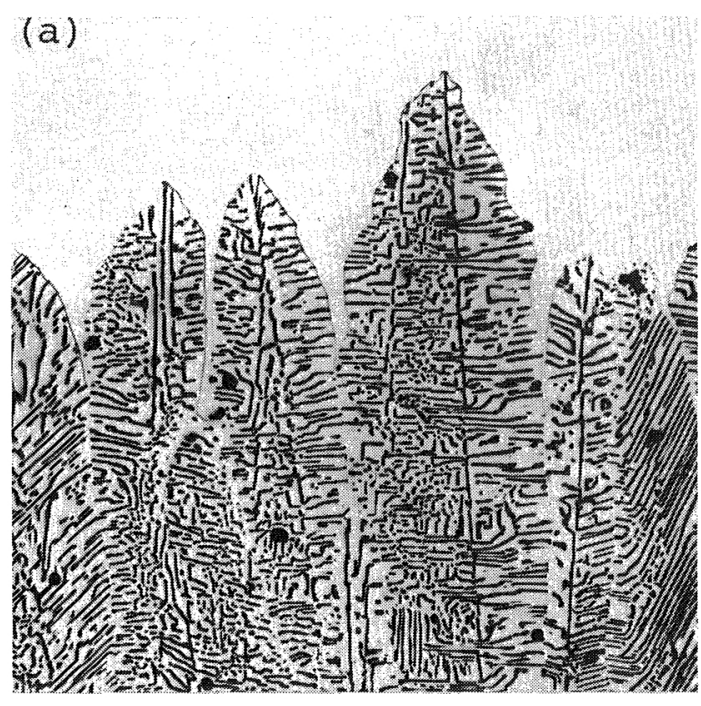

Longitudinal Section

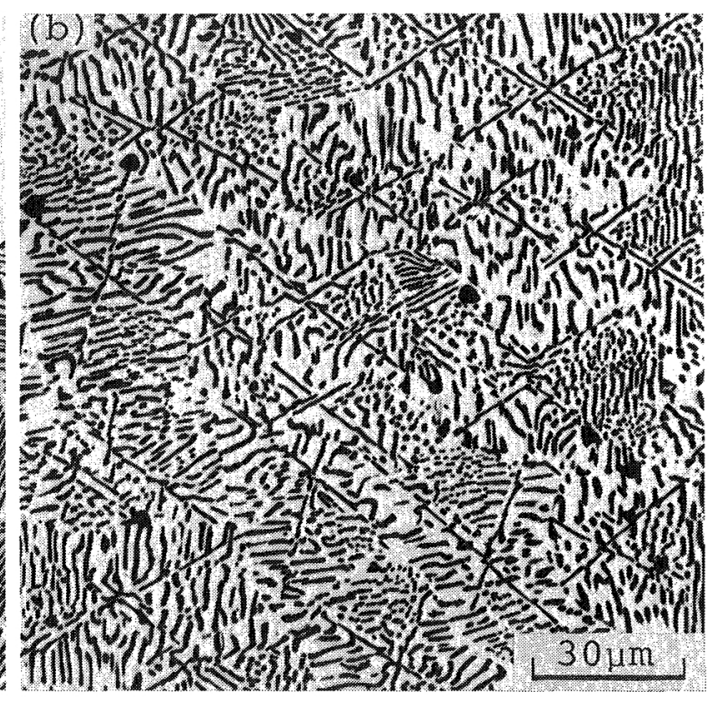

Transverse Section

Photo. 3 Cellular $\delta$-pearlite produced by carburizing $\mathrm{Fe}-16.0 \mathrm{wt} \% \mathrm{Cr}-3.44 \mathrm{wt} \% \mathrm{Mo}$ alloy at $1313 \mathrm{~K}$.
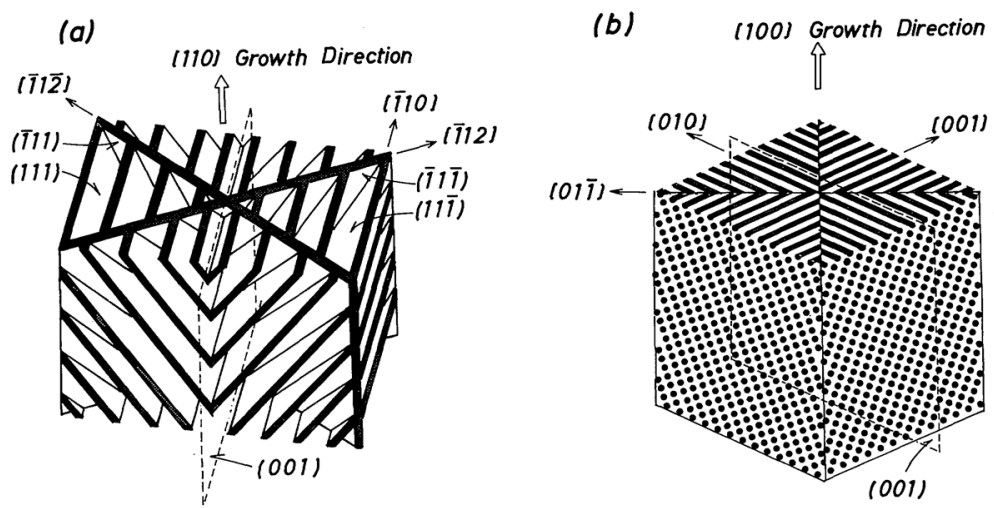

Fig. 2 Estimated configuration of carbide in cellular $\delta$-pearlite. (a) $\mathrm{M}_{23} \mathrm{C}_{6}$ carbide in $\mathrm{Fe}-\mathrm{Cr}-$ $\mathrm{M}-\mathrm{C} \delta$-pearlite. (b) $\mathrm{M}_{6} \mathrm{C}$ carbide in Fe-W-M-C $\delta$-pearlite. 
about $70^{\circ}$ and the secondary arms are also plates, lying at an angle of about $55^{\circ}$ with the primary arms on the transverse section. The morphological feature of the dendritic carbides is explained by the following crystallographic considerations. It has been clarified that a cube-cube orientation relationship is satisfied in austenite and $\mathrm{M}_{23} \mathrm{C}_{6}$ phases in $\delta$-pearlite, and both phases grow in the [110] direction with $\{111\}$ habit planes ${ }^{(9)}$. Based on the results, the structure shown in Photo. 3(b) is interpreted by considering that the primary carbide arms have (111) and (111) habit planes parallel to the [110] growth direction and the secondary arms have (111) and (111) habit planes inclined to the [110] direction. The configuration of $\mathrm{M}_{23} \mathrm{C}_{6}$ carbide in the cellular $\delta$-pearlite of the alloy is schematically shown in Fig. 2(a).

It was found that nickel and phosphorus had a pronounced effect on the $\delta$-pearlite structure. Photograph 4(a) is an example of $\delta$-pearlite structure in the carburized $\mathrm{Fe}-\mathrm{Cr}-\mathrm{Ni}$ alloy. The cellular structure was observed even in the alloys containing only about $0.3 \mathrm{wt} \% \mathrm{Ni}$ and independent growth of austenite and carbide was seen in the alloys with more than about $2.2 \mathrm{wt} \% \mathrm{Ni}$. An addition of small amount of phosphorus makes the $\delta$-pearlite structure

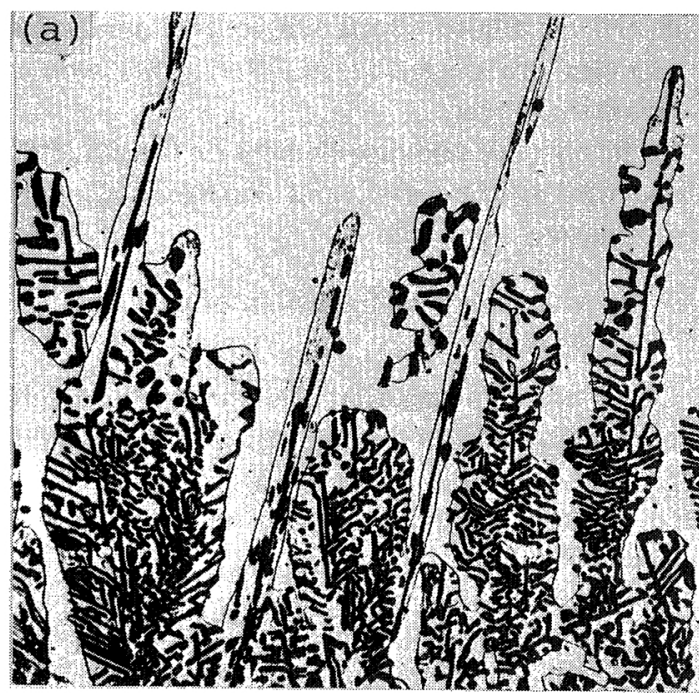

(c)

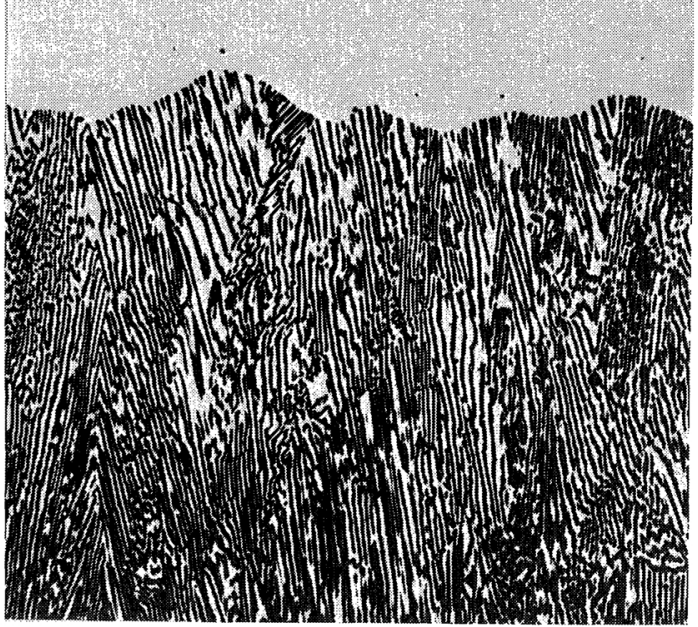

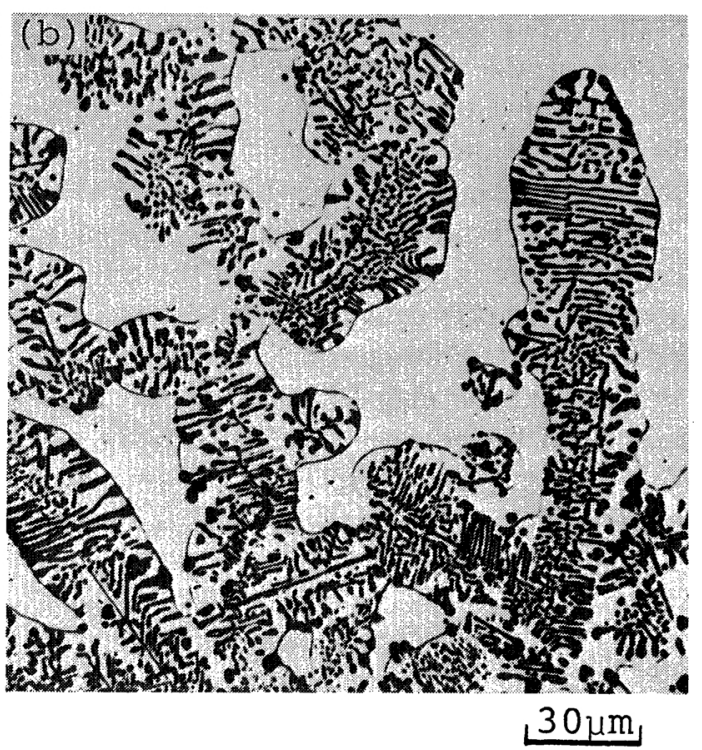

Photo. 4 Delta-pearlite produced by carburizing Fe-Cr-M alloys. (a) Fe-23.2 wt $\% \mathrm{Cr}-1.99 \mathrm{wt} \% \mathrm{Ni}$ alloy carburized at $1273 \mathrm{~K}$. (b) $\mathrm{Fe}-16.7 \mathrm{wt} \% \mathrm{Cr}-$ $0.53 \mathrm{wt} \% \mathrm{P}$ alloy carburized at $1273 \mathrm{~K}$. (c) $\mathrm{Fe}-20.2$ wt $\% \mathrm{Cr}-1.80 \mathrm{wt} \% \mathrm{Mn}$ alloy carburized at $1203 \mathrm{~K}$. 
dendritic as seen in Photo. 4(b). In Fe-Cr-Mn alloys, the structure was little influenced by the addition of manganese up to about $2.2 \mathrm{wt} \%$ as shown in Photo. 4(c).

\section{(2) Structure in $\mathrm{Fe}-\mathrm{W}-\mathrm{M}-\mathrm{C}$ alloys}

Photograph 5 shows longitudinal and transverse sections of $\delta$-pearlite produced by carburizing the $\mathrm{Fe}-15.8 \mathrm{wt} \% \mathrm{~W}$ alloy. As in the $\mathrm{Fe}-\mathrm{Cr}-\mathrm{C}$ alloy, the well aligned structure composed of austenite and plate- or rodshaped $\mathrm{M}_{6} \mathrm{C}$ carbide are formed.

With an addition of silicon to $\mathrm{Fe}-\mathrm{W}-\mathrm{C}$ alloy, the morphological change in $\delta$-pearlite structure similar to that in $\mathrm{Fe}-\mathrm{Cr}-\mathrm{Si}-\mathrm{C}$ alloys occurred as shown in Photo. 6. In the alloys with more than $3 \mathrm{wt} \% \mathrm{Si}$, austenite and carbide grow independently as seen in Photo. 6(c).

Photograph 7 shows the longitudinal and the transverse sections of cellular $\delta$-pearlite produced by carburizing $\mathrm{Fe}-12.9 \mathrm{wt} \% \mathrm{~W}-2.01$ wt $\%$ Si alloy. Photograph 7(b) was taken at a transverse section a little behind the cell tips so that the pearlite cells are separately seen in $\delta$-ferrite matrix. Photographs 7(c) and (d) were taken under higher magnification. These photographs seem to indicate that the primary and secondary arms grow preferentially in $\langle 100\rangle$ directions of the carbide, as verified in dendritic solidification of cubic crystals $^{(10)}$. The configuration of $\mathrm{M}_{6} \mathrm{C}$ carbide, which has a complex $f c c$ structure, in the cellular $\delta$-pearlite of the $\mathrm{Fe}-\mathrm{W}-\mathrm{Si}-\mathrm{C}$ alloy is illustrated in Fig. 2(b).

Photograph 8 shows the effect of chromium, nickel and manganese on the $\delta$-pearlite in $\mathrm{Fe}-\mathrm{W}-\mathrm{C}$ alloy. Chromium hardly affects the eutectoid structure up to about $5 \mathrm{wt} \%$. Nickel makes the reaction front of $\delta$-pearlite cellular and carbides fibrous. It was observed that intermetallic compound $\mathrm{Fe}_{3} \mathrm{~W}_{2}$ tended to be formed by an addition of nickel $(>2 \mathrm{wt} \%$ ) and manganese $(>1 \mathrm{wt} \%$ ). In carburization, the compound particles interfere the $\delta$-eutectoid transformation, and spoil the alignment of $\delta$-pearlite. Typical example of the structure is shown in Photo. 8(c), where the compound particles are dispersed in $\delta$-ferrite as well as carburized layer.

The effect of alloying element on the eutectoid structure of $\mathrm{Fe}-\mathrm{Cr}-\mathrm{C}$ and $\mathrm{Fe}-\mathrm{W}-\mathrm{C}$ alloys is summarized in Table 2.

\section{Mechanism of formation of cellular $\delta$-pearlite}

It is well known that the shape of eutectic solidification front changes from planar to cellular due to an addition of impurities ${ }^{(11) \sim(14)}$. The change in interface shape of eutectic alloys

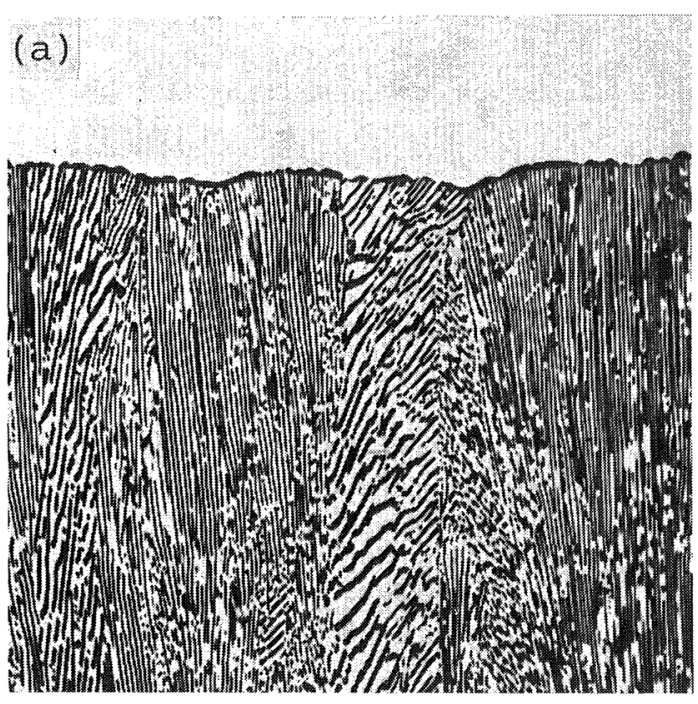

Longitudinal Section

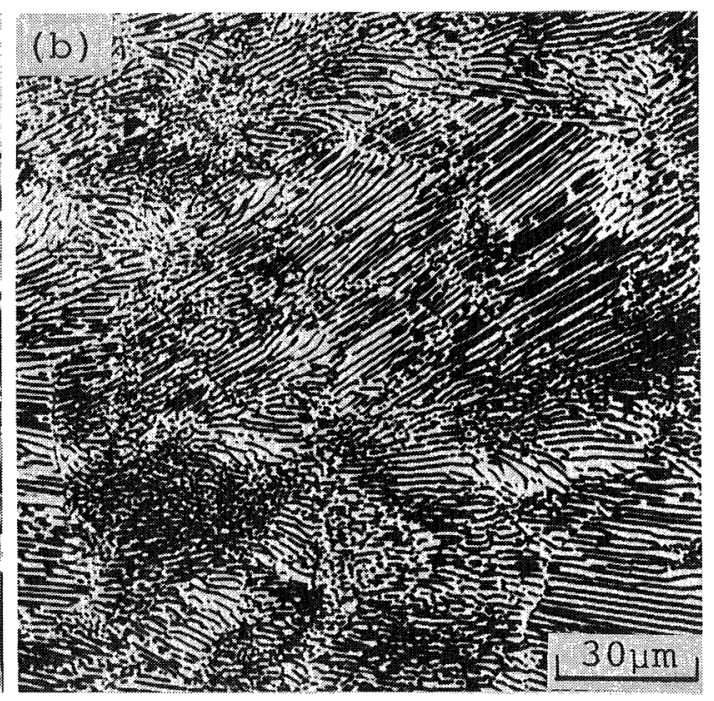

Transverse Section

Photo. 5 Delta-pearlite produced by carburizing Fe-15.8 wt \%W alloy at $1473 \mathrm{~K}$. 
(a)
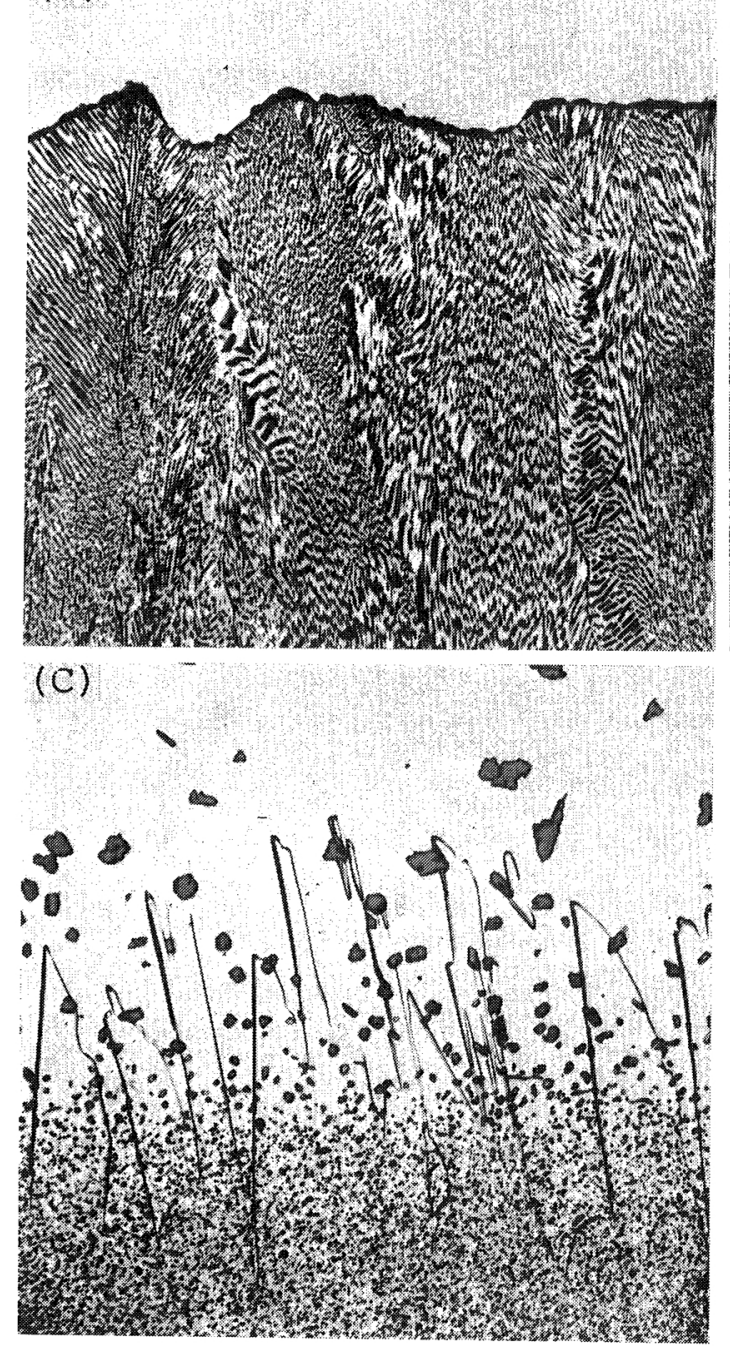

(b)

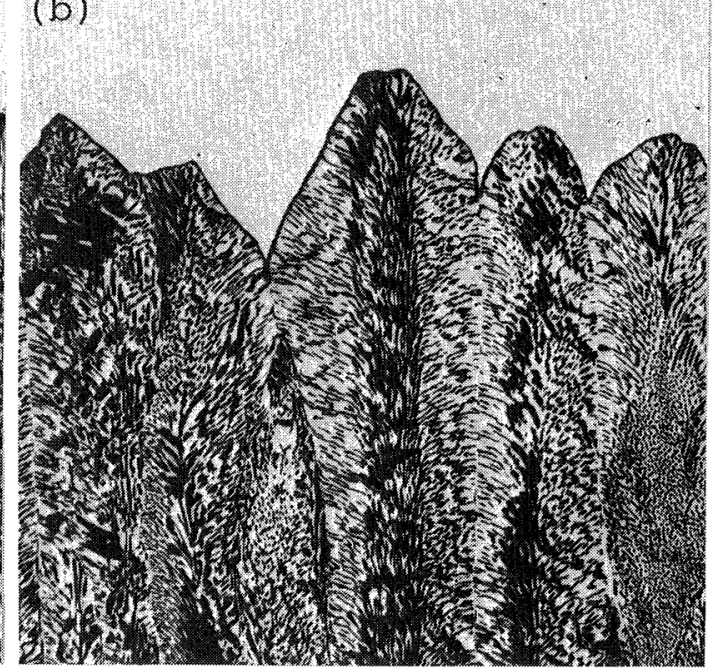

$30 \mu \mathrm{m}$

Photo. 6 Microstructures obtained by carburizing Fe-W-Si alloys. (a) Fe-15.3 wt $\% \mathrm{~W}-0.52 \mathrm{wt} \% \mathrm{Si}$ alloy carburized at $1473 \mathrm{~K}$. (b) $\mathrm{Fe}-10.0 \mathrm{wt} \% \mathrm{~W}-$ $0.93 \mathrm{wt} \% \mathrm{Si}$ alloy carburized at $1373 \mathrm{~K}$. (c) $\mathrm{Fe}-12.0$ wt $\% \mathrm{~W}-3.00 \mathrm{wt} \% \mathrm{Si}$ alloy carburized at $1473 \mathrm{~K}$.

is generally interpreted by the idea of constitutional supercooling caused by partitioning of impurities ${ }^{(15)}$. As mentioned in the previous paper ${ }^{(1)}$, there are striking similarities between $\delta$-eutectoid transformation induced by carburization and unidirectional eutectic solidification, except for the fact that the former is induced by carbon concentration gradient and the latter by temperature gradient. It is, therefore, expected that the idea of constitutional supercooling is applied to explain the change in interface shape of $\delta$-pearlite by the addition of alloying element. The basic idea of constitutional supercooling is as follows ${ }^{(2)}$.
During solidification of alloys, the liquid adjacent to solid/liquid interface has a different composition with bulk liquid. When the partitioning coefficient of solute is less than unity, the solute concentration in an adjacent region with the interface is higher than that in bulk liquid and, correspondingly, the liquidus temperature lowers in the region. If the temperature gradient ahead of the interface is small enough to produce a supercooled liquid in the region, the cellular structure will be developed.

In the case of $\delta$-eutectoid transformation induced by carburization, the carbon super- 

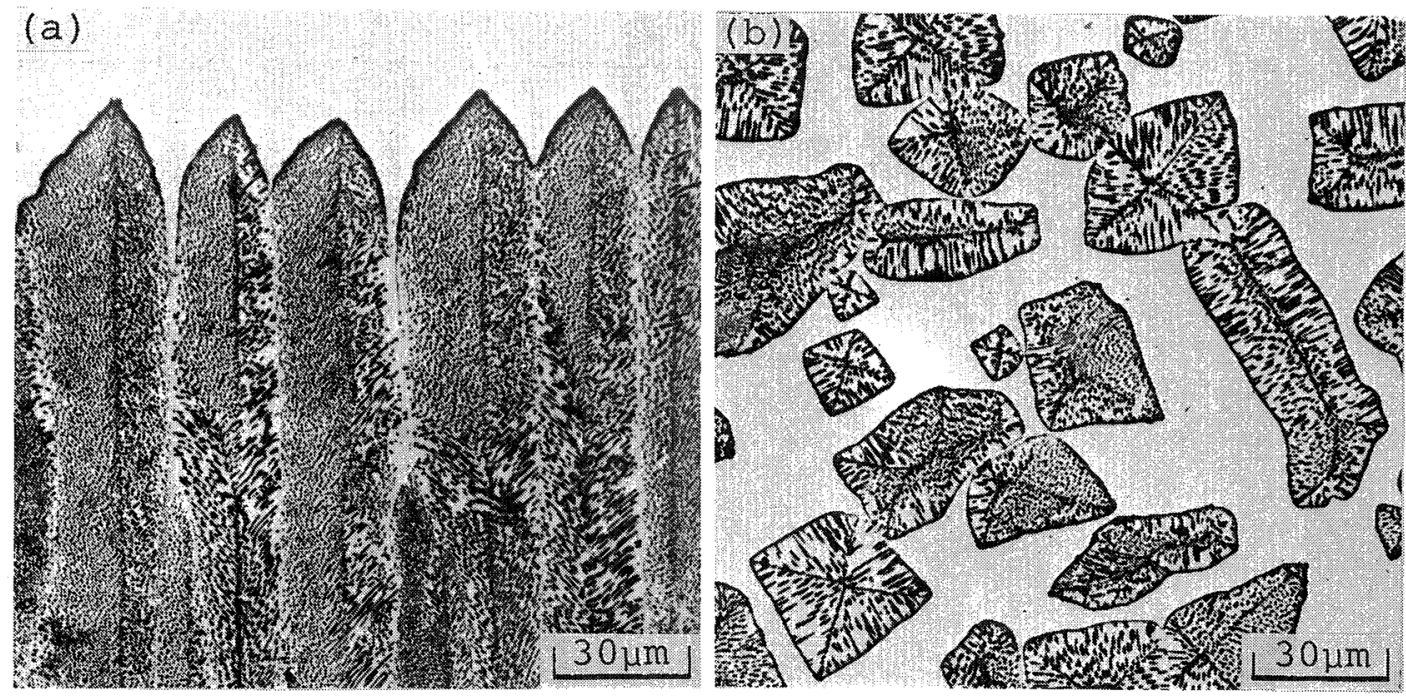

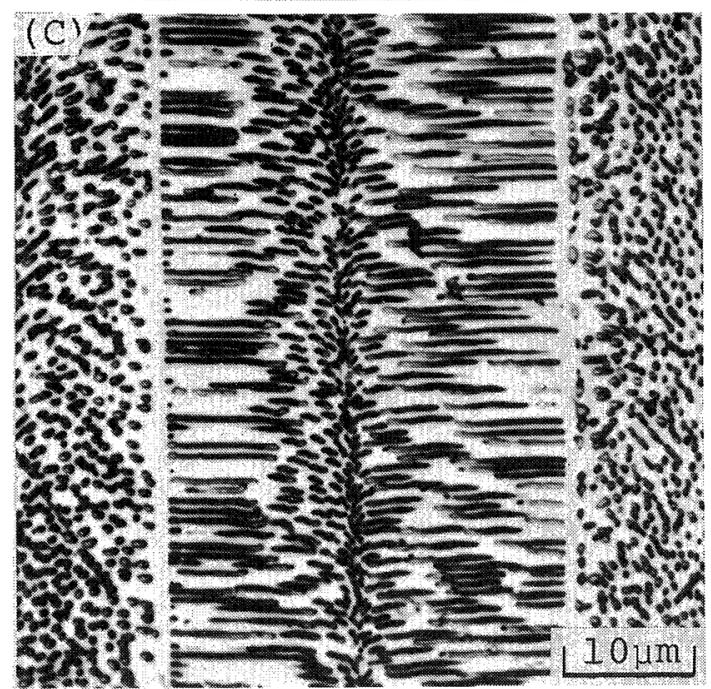

Longitudinal Section

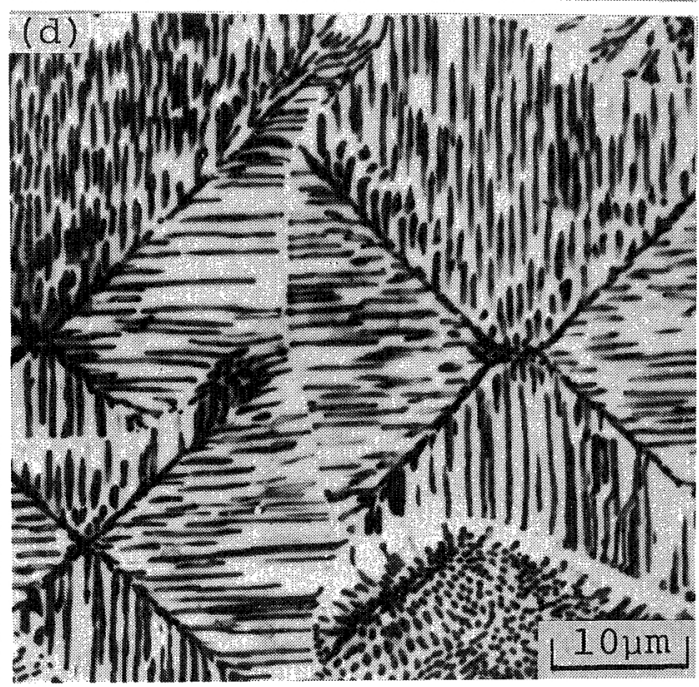

Transverse Section

Photo. 7 Longitudinal and transverse sections of cellular $\delta$-pearlite produced by carburizing $\mathrm{Fe}-12.9 \mathrm{wt} \% \mathrm{~W}-2.01 \mathrm{wt} \% \mathrm{Si}$ alloy at $1503 \mathrm{~K}$.

saturated region will be induced by the formation of positive or negative spike of substitutional element in $\delta$-ferrite ahead of the interface. The distributions of substitutional elements around the reaction front are illustrated in Fig. 3. If the alloying element $M$ stabilizes ferrite, a positive spike of $M$ will be formed as shown in Fig. 3(a-1). It is expected from Fig. 1 that the enrichment of ferrite stabilizer causes the eutectoid composition of chromium or tungsten to be lowered. It follows that a negative spike of chromium or tungsten is also produced as shown in Fig. 3(a-2). If the alloying element $M$ stabilizes austenite, negative spikes of $M$ and chromium or tungsten will be formed as shown in Fig. 3(b-1) and (b-2).

As a result of the formation of the spikes, a supersaturated region of carbon will be generated in $\delta$-ferrite ahead of the reaction front. In Fig. 4, the concentration profile of carbon in the vicinity of the reaction front during carburization is given. The broken line 
(a)
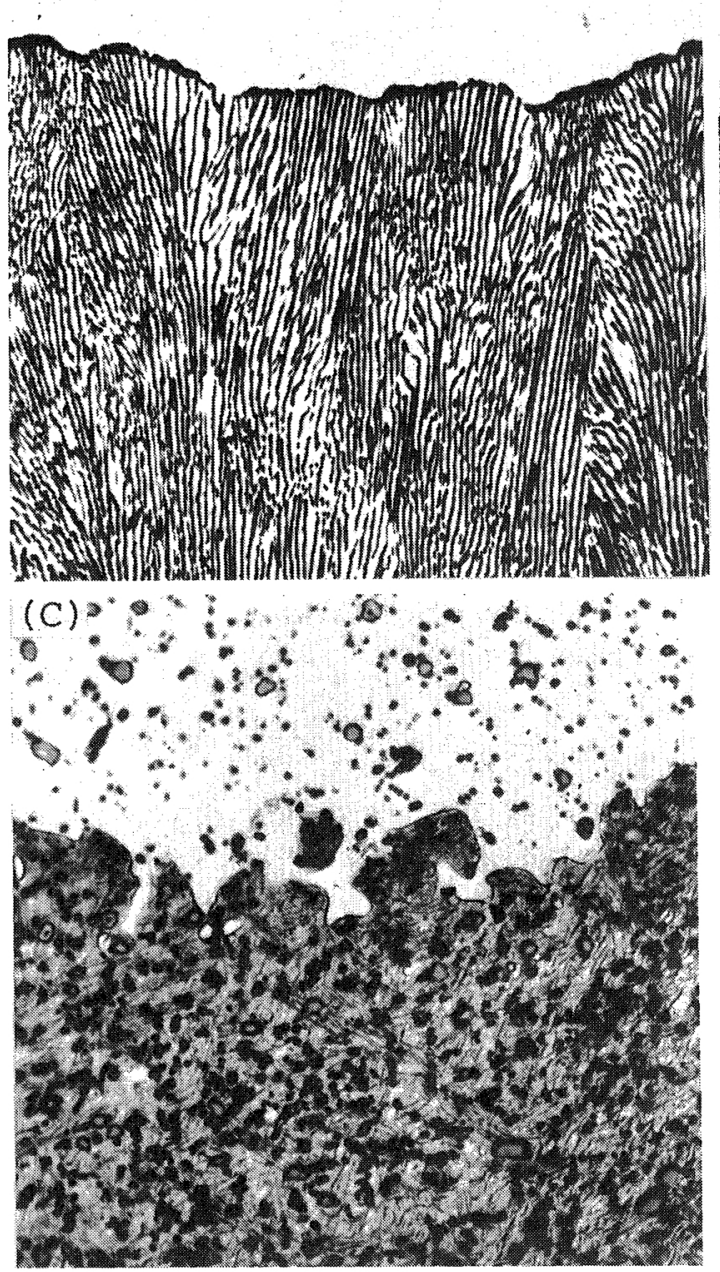

(b)

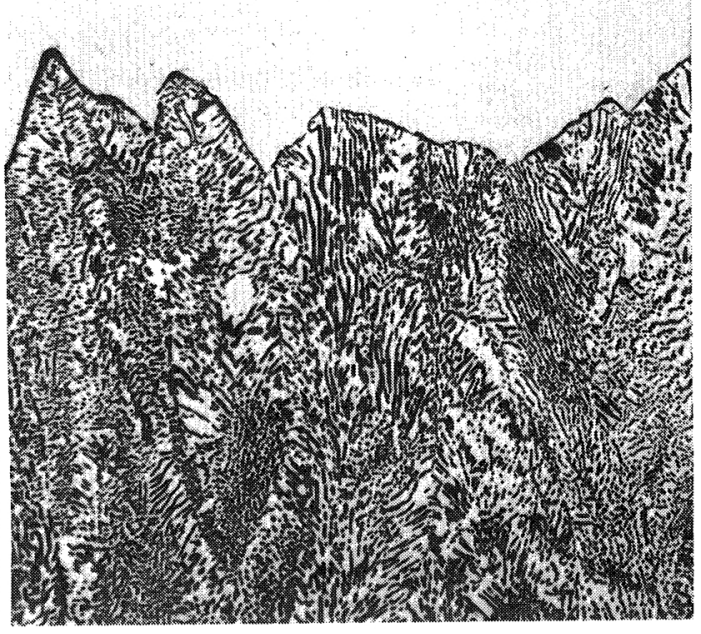

$30 \mu \mathrm{m}$

Photo. 8 Microstructures obtained by carburizing $\mathrm{Fe}-\mathrm{W}-\mathrm{M}$ alloys. (a) $\mathrm{Fe}-15.4 \mathrm{wt} \% \mathrm{~W}-3.71 \mathrm{wt} \% \mathrm{Cr}$ alloy carburized at $1493 \mathrm{~K}$. (b) Fe-15.4 wt \%W$1.08 \mathrm{wt} \% \mathrm{Ni}$ alloy carburized at $1473 \mathrm{~K}$. (c) $\mathrm{Fe}-14.6$ wt $\% \mathrm{~W}-1.41 \mathrm{wt} \% \mathrm{Mn}$ alloy carburized at $1423 \mathrm{~K}$.

$$
x_{\mathrm{M}}^{\delta}(z)={ }^{0} x_{\mathrm{M}}^{\delta}\left\{1+\frac{1-k_{\mathrm{M}}}{k_{\mathrm{M}}} \exp \left(-\frac{v z}{D_{\mathrm{M}}^{\delta}}\right)\right\},
$$

shows the change in solubility of carbon in
$\delta$-ferrite, which arises from the spikes of substitutional elements as described in Fig. 3. It seems reasonable that the change in carbon concentration in $\delta$-ferrite ahead of the reaction front is small compared to the solubility change caused by the spike of substitutional solutes because of high diffusivity of carbon. Consequently, a supersaturated region for carbon is produced in $\delta$-ferrite as a hatched area in Fig. 4.

If the reaction front moves with a constant velocity $v$, the concentration profile of $\mathrm{M}$ ahead of the front is approximated to $b^{(2)}$ where ${ }^{0} x_{M}^{\delta}$ is the initial concentration of solute $\mathrm{M}, k_{\mathrm{M}}$ is the average partitioning coefficient of $\mathrm{M}$ between $\delta$-pearlite and $\delta$-ferrite, $D_{\mathrm{M}}^{\delta}$ is the diffusion coefficient of $\mathrm{M}$ in $\delta$-ferrite and $z$ is the distance normal to the reaction front, respectively. The profile expected from eq. (2) is schematically drawn in Fig. 5. The thickness of the spike $\Delta z_{\mathrm{M}}$ is approximated by an intersection $\mathrm{OB}$ in Fig. 5, which is given by the following equation: 
Table 2 Effect of alloying element on $\delta$-pearlite structure.

\begin{tabular}{|c|c|c|c|c|c|c|}
\hline \multirow{2}{*}{$\begin{array}{c}\text { Basic } \\
\text { system }\end{array}$} & \multirow{2}{*}{$\begin{array}{c}\text { Alloy- } \\
\text { ing } \\
\text { ele-- } \\
\text { ment }\end{array}$} & \multicolumn{5}{|c|}{ Content of alloying element (wt $\%$ ) } \\
\hline & & 0.3 & 0.5 & 1 & 2 & 3 \\
\hline \multirow{5}{*}{$\mathrm{Fe}-\mathrm{Cr}-\mathrm{C}$} & $\mathbf{P}$ & - & $C \sim D$ & - & - & 一 \\
\hline & Mo & - & - & B & $B \sim C$ & $\mathrm{C}$ \\
\hline & $\mathrm{Si}$ & A & $A \sim B$ & $\mathbf{C}$ & D & $\mathrm{E}$ \\
\hline & $\mathrm{Ni}$ & $\mathbf{B}$ & $\mathrm{B} \sim \mathrm{C}$ & C & $C \sim D$ & $C \sim D$ \\
\hline & Mn & 一 & - & A & $\mathbf{A} \sim \mathbf{B}$ & - \\
\hline \multirow{4}{*}{$\mathrm{Fe}-\mathrm{W}-\mathrm{C}$} & Si & - & $A \sim B$ & $\mathrm{~B} \sim \mathrm{C}$ & $\mathbf{C}$ & $\mathrm{E}$ \\
\hline & $\mathrm{Cr}$ & - & - & - & - & $\mathbf{A}$ \\
\hline & $\mathrm{Ni}$ & $A \sim B$ & - & $\mathrm{B} \sim \mathrm{C}$ & $C \sim D$ & $\mathrm{E}^{*}$ \\
\hline & Mn & - & - & $D^{*}$ & $\mathrm{D}^{*}$ & $\mathrm{E}^{*}$ \\
\hline
\end{tabular}

A: Well aligned lamellar structure

B: Mixed structure of $\mathbf{A}$ and $\mathbf{C}$

C: Well developed cellular structure

D: Mixed structure of $\mathbf{C}$ and $\mathbf{E}$

$\mathrm{E}$ : Independent growth of austenite and carbide

*: $\mathrm{Fe}_{3} \mathrm{~W}_{2}$ compound appears

(a) ferrite stabilizer addition

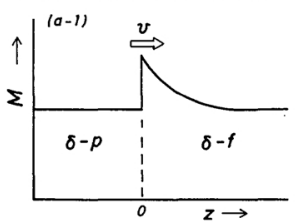

(b) austenite stabilizer addition
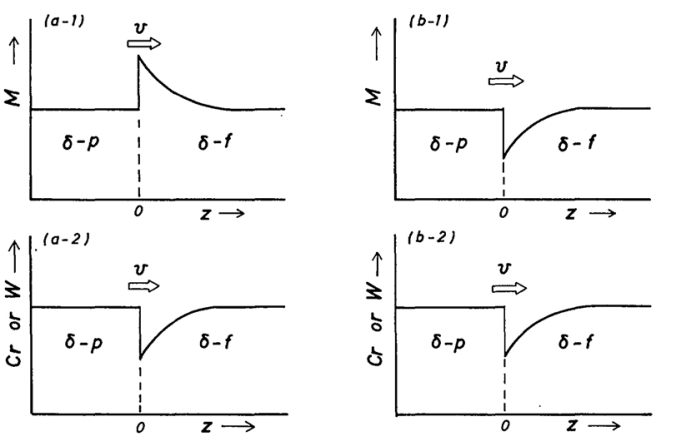

Fig. 3 Schematic representation of the solute distributions around the reaction front. The figure is drawn on the assumption that the local equilibrium is maintained at the front. (a) $M$ is a ferritestabilizing element. (b) $\mathrm{M}$ is an austenite-stabilizing element.

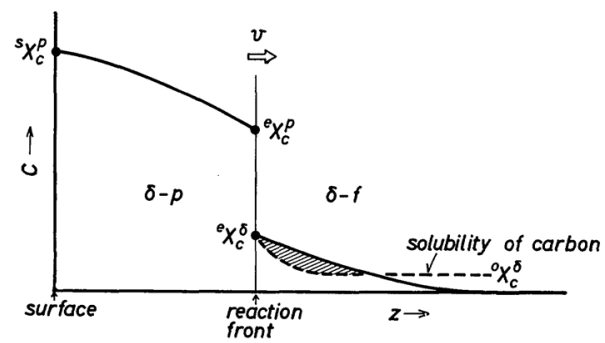

Fig. 4 Illustration of the generation of supersaturated $\delta$-ferrite ahead of the reaction front.

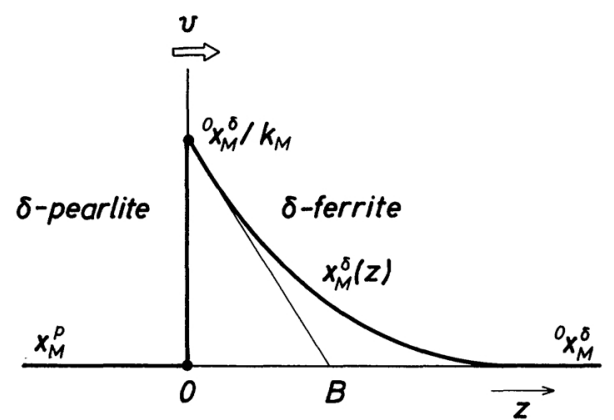

Fig. 5 Solute distribution ahead of the reaction front.

$$
\Delta z_{\mathrm{M}}=\frac{D_{\mathrm{M}}^{\delta}}{v} .
$$

As has been pointed out in the previous paper ${ }^{(1)}$, the growth velocity of $\delta$-pearlite is expressed by

$$
v=\frac{\xi}{2\left(t-t_{0}\right)},
$$

where $\xi$ is the penetration depth, $t$ is the carburizing time and $t_{0}$ is the incubation time. The thickness $\Delta z_{\mathbf{M}}$ is obtained from eqs. (3) and (4) as

$$
\Delta z_{\mathrm{M}}=\frac{2 D_{\mathrm{M}}^{\delta}\left(t-t_{0}\right)}{\xi} .
$$

A rough evaluation from eq. (5) reveals that the thickness is an order of $10^{-6} \sim 10^{-5} \mathrm{~m}$ at the conditions examined in this work, and then detectable by EPMA analysis.

Figure 6 shows the solute distribution in front of the tip of $\delta$-pearlite cell in $\mathrm{Fe}-\mathrm{Cr}-\mathrm{M}$ $\mathrm{C}$ alloys. A positive spike of molybdenum and negative spike of chromium are seen in Fig. 6(a) and negative spikes of both nickel and chromium are seen in Fig. 6(b) as expected from Fig. 3. The thicknesses of the spikes estimated by EPMA analysis were compared with those calculated from eq. (5) in Table 3. The calculated and observed values agree well with each other in every alloy. The fact indicates that the formation of cellular $\delta$-pearlite is caused by the supersaturation of carbon in $\delta$-ferrite as illustrated in Fig. 4.

Since the supersaturation is generated by the existence of the spike of substitutional solutes, the degree of the supersaturation increases with 
the increase of the spike height. It is expected from Fig. 5 that the spike height will increase when the amount of alloying element increases and/or the partitioning coefficient $k_{\mathrm{M}}$ becomes far from unity. The values of $k_{\mathrm{M}}$ can roughly be estimated from the partitioning coefficient of $M$ between ferrite and austenite, because the volume fraction of carbide in $\delta$-pearlite is less than 0.05 for all alloys examined ${ }^{(1)}$. Then, it is expected that $k_{\mathrm{M}}$ takes a value far from unity if $M$ has a strong tendency to stabilize ferrite or austenite. A typical example is observed in the alloy containing phosphorus, which strongly stabilizes ferrite and has a marked effect on the modification of $\delta$-pearlite
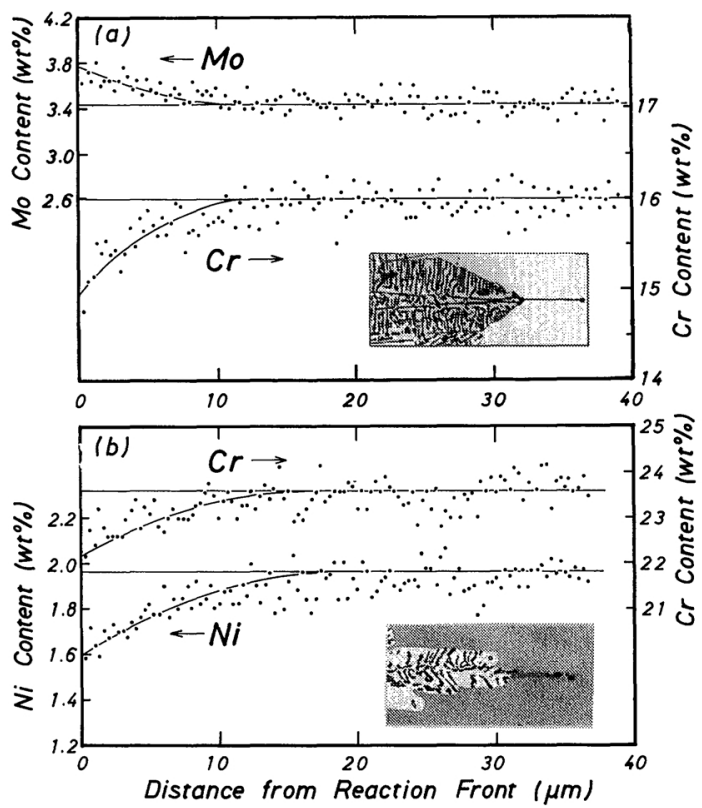

Fig. 6 Solute distribution ahead of the tip of $\delta$ pearlite cell. (a) $\mathrm{Fe}-16.0 \mathrm{wt} \% \mathrm{Cr}-3.44 \mathrm{wt} \% \mathrm{Mo}$ alloy carburized at $1313 \mathrm{~K}$ for $16 \mathrm{~h}$. (b) Fe-23.2 wt \% $\mathrm{Cr}-1.99 \mathrm{wt} \% \mathrm{Ni}$ alloy carburized at $1273 \mathrm{~K}$ for $25 \mathrm{~h}$. in $\mathrm{Fe}-\mathrm{Cr}-\mathrm{C}$ alloy as shown in Photo. 4(b). On the other hand, the $\delta$-pearlite in $\mathrm{Fe}-\mathrm{W}-\mathrm{C}$ alloy is hardly affected by the addition of chromium, which stabilizes ferrite to a little extent at the temperature range examined.

Figure 7 shows the solute distribution in $\delta$-ferrite ahead of the cell boundary. As has been found in cellular solidification structure ${ }^{(16)}$, solute segregations of the same sign as the solute spikes at the cell tip are observed. It should be noticed in Fig. 7 that the negative segregation of chromium is remarkable. This
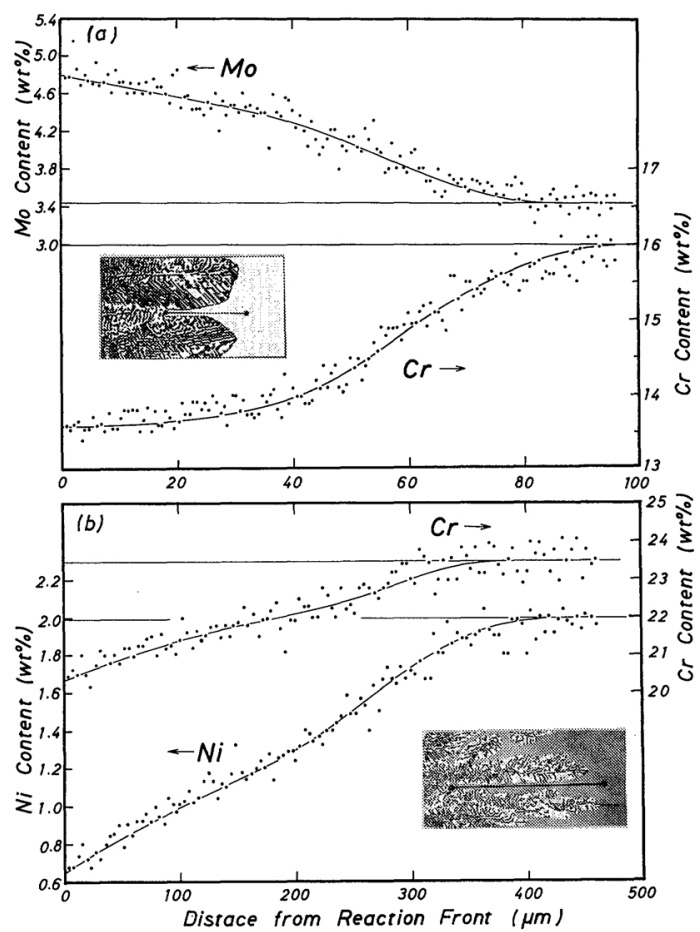

Fig. 7 Solute distribution ahead of cell boundary. (a) $\mathrm{Fe}-16.0 \mathrm{wt} \% \mathrm{Cr}-3.44 \mathrm{wt} \% \mathrm{Mo}$ alloy carburized at $1313 \mathrm{~K}$ for $16 \mathrm{~h}$. (b) $\mathrm{Fe}-23.2 \mathrm{wt} \% \mathrm{Cr}-1.99 \mathrm{wt} \% \mathrm{Ni}$ alloy carburized at $1273 \mathrm{~K}$ for $25 \mathrm{~h}$.

Table 3 Comparison of the calculated and observed thickness of spike.

\begin{tabular}{|c|c|c|c|c|c|c|c|c|c|}
\hline \multirow{2}{*}{$\begin{array}{l}\mathrm{Fe}-\mathrm{M}_{1}-\mathrm{M}_{2} \\
\text { alloys }\end{array}$} & \multirow{2}{*}{$\begin{array}{l}\text { Tempera- } \\
\text { ture }(\mathbf{K})\end{array}$} & \multirow{2}{*}{$\begin{array}{l}t-t_{0} \\
(\mathrm{~s})\end{array}$} & \multirow{2}{*}{$\begin{array}{l}\xi \\
(\mathrm{m})\end{array}$} & \multirow{2}{*}{$\underset{\left(\mathrm{m}^{2} / \mathrm{s}\right)}{D_{\mathrm{M}_{1}}^{\delta}}$} & \multirow{2}{*}{$\begin{array}{c}D_{\mathrm{M}_{2}}^{\delta} \\
\left(\mathrm{m}^{2} / \mathrm{s}\right)\end{array}$} & \multicolumn{2}{|c|}{$\Delta z_{\mathbf{M}_{1}}(\mu \mathrm{m})$} & \multicolumn{2}{|c|}{$\Delta z_{\mathbf{M}_{2}}(\mu \mathrm{m})$} \\
\hline & & & & & & calc. & exp. & calc. & exp. \\
\hline $\mathrm{Fe}-16.0 \mathrm{Cr}-3.44 \mathrm{Mo}$ & 1313 & $5.8 \times 10^{4}$ & $1.6 \times 10^{-3}$ & $1.0 \times 10^{-13}$ & $1.0 \times 10^{-13}$ & 7 & 7 & 7 & 7 \\
\hline $\mathrm{Fe}-16.9 \mathrm{Cr}-1.80 \mathrm{Si}$ & 1293 & $2.2 \times 10^{4}$ & $0.7 \times 10^{-3}$ & $0.8 \times 10^{-13}$ & $3.3 \times 10^{-13}$ & 5 & 10 & 21 & 20 \\
\hline $\mathrm{Fe}-23.2 \mathrm{Cr}-1.99 \mathrm{Ni}$ & 1273 & $9.0 \times 10^{4}$ & $1.0 \times 10^{-3}$ & $0.6 \times 10^{-13}$ & $0.6 \times 10^{-13}$ & 11 & 10 & 11 & 10 \\
\hline $\mathrm{Fe}-12.9 \mathrm{~W}-2.01 \mathrm{Si}$ & 1503 & $1.8 \times 10^{3}$ & $0.7 \times 10^{-3}$ & $1.0 \times 10^{-12}$ & $5.0 \times 10^{-12}$ & 5 & 7 & 25 & 15 \\
\hline
\end{tabular}


causes the carbon content in ferrite as well as austenite at the reaction front to be increased, and the growth velocity of $\delta$-pearlite to be lowered at the cell boundary. As a result, the boundary groove develops with the progress of the $\delta$-eutectoid transformation.

\section{Conclusions}

Effect of alloying element on the $\delta$-pearlite structure of carburized $\mathrm{Fe}-\mathrm{Cr}$ and $\mathrm{Fe}-\mathrm{W}$ alloys was studied in detail, and the following results were obtained.

(1) The chromium or tungsten content in eutectoid alloys decreases with addition of a ferrite-stabilizing element and increases with addition of an austenite-stabilizing element.

(2) The structure changes with the type and the amount of alloying element. With the increase of the alloying element, the structural change occurs in the following manner; the generation of nonplanar reaction front, the development of cellular structures, and finally the independent growth of austenite and carbide.

(3) The formation of the cellular structure is due to the supersaturation of carbon caused by the formation of spike of alloying element in $\delta$-ferrite ahead of the reaction front.

\section{Acknowledgments}

The authors wish to express their gratitude to Professor Mats Hillert, The Royal Institute of Technology, Stockholm, for his kind advice and encouragement. They are also indebted to Mr. Y. Tanaka, Komatsu, Ltd., Osaka, and Mr. I. Saijo, Shinagawa Furnace Co., Ltd., Tokyo, for the generous assistance in carrying out the experiments.

\section{REFERENCES}

(1) T. Saito, T. Sakuma and T. Nishizawa: Trans. Japan Inst. Metals, 21 (1980), 471.

(2) W. A. Tiller, K. A. Jackson, J. W. Rutter and B. Chalmers: Acta. Met., 1 (1953), 428.

(3) D. E. Coates and J. S. Kirkaldy: Trans. ASM, 62 (1969), 426.

(4) J. S. Kirkaldy and D. G. Fedak: Trans. Met. Soc. AIME, 224 (1962), 490.

(5) C. W. Taylor, Jr., M. A. Dayananda and R. E. Grace: Met. Trans., 1 (1970), 127.

(6) P. G. Shewmon: Trans. Met. Soc. AIME, 233 (1965), 736.

(7) C. Wagner: J. Electrochem. Soc., 103 (1956), 571.

(8) T. O. Ziebold and R. E. Ogilvie: Anal. Chem., 35 (1963), 621.

(9) T. Sakuma, M. Haga and T. Nishizawa: Trans. Japan Inst. Met., 16 (1975), 225.

(10) H. W. Weart and D. J. Mack: Trans. Met. Soc. AIME, 212 (1958), 664.

(11) J. E. Gruzleski and W. C. Winegard: Trans. Met. Soc. AIME, 242 (1968), 1785.

(12) J. E. Gruzleski and W. C. Winegard: J. Inst. Metals, 96 (1968), 304.

(13) D. Jaffrey and G. A. Chadwick: ibid., 97 (1969), 118.

(14) J. B. Bullock, C. J. Simpson, J. A. Eady and W. C. Winegard: ibid., 99 (1971), 212.

(15) G. A. Chadwick: ibid., 91 (1961), 298.

(16) J. J. Kramer, G. F. Bolling and W. A. Tiller: Trans. Met. Soc. AIME, 227 (1963), 374. 